\title{
Design of Production Systems for the MACHINE AND Plant ENGINEERING INDUSTRY
}

\author{
GRABENWEGER, J. \& NITKA, F.
}

Abstract: Within the context of design and implementation of a customized comprehensive production system, many industrial companies are coping with the issue of how the subsystems respectively principles of lean manufacturing can be utilized for the company in question in a way that is consistent with the sector. This report looks at one possible approach that differentiates between an adaptive and a hybrid method for the implementation of these principles. These methods are illustrated within the machine and plant engineering environment by means of two examples. The approach described can be used to support companies within the sector in developing and implementing their own production systems, to verify their status achieved to date, or as a support tool in further developments.

Key words: comprehensive production system, machine and plant engineering, Kanban, continuous improvement process, lean manufacturing
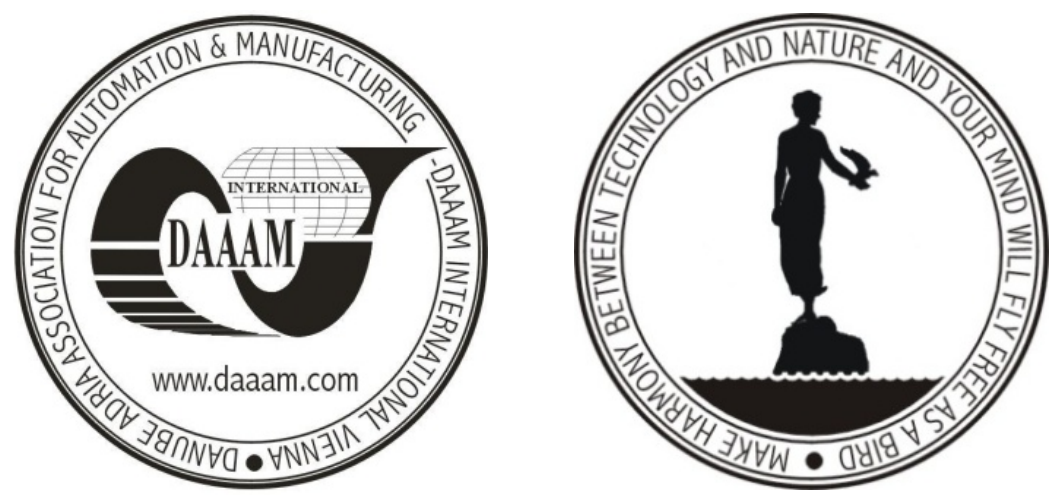

Author's data: Dr. tech. Dipl.-Ing. Grabenweger, J[ohann]* MBA; Dipl.-Logist. Nitka, F[rederic]**, *Chief Operations Officer, KHS AG, Juchostrasse 20, 44143 Dortmund, Germany, **Industrial Engineer, KHS AG DO plant, Juchostrasse 20, 44143 Dortmund, Germany, johann.grabenweger@khs.com, frederic.nitka@khs.com

This Publication has to be referred as: Grabenweger, J[ohann] \& Nitka, F[rederic] (2009). Design of Production Systems for the Machine and Plant Engineering Industry, Chapter 64 in DAAAM International Scientific Book 2009, pp. 665-674, B. Katalinic (Ed.), Published by DAAAM International, ISBN 978-3-901509-69-8, ISSN 1726-9687, Vienna, Austria

DOI:10.2507/daaam.scibook.2009.64 